\title{
How Slight Solidification Rate Variations within Cast Plate Affect Mechanical Response: A Study on As-Cast A356 Alloy with Cu Additions
}

\author{
Maria Teresa Di Giovanni, ${ }^{1}$ Emanuela Cerri $\mathbb{D D}^{1},{ }^{1}$ Takeshi Saito $\mathbb{D}^{2},{ }^{2}$ Shahid Akhtar, \\ Petter Åsholt, ${ }^{2}$ Yanjun Li, ${ }^{3}$ and Marisa Di Sabatino ${ }^{3}$ \\ ${ }^{1}$ Department of Engineering and Architecture, University of Parma, Viale G. Usberti 18/A, 43124 Parma, Italy \\ ${ }^{2}$ Hydro Aluminium, Research and Technology Development (RTD), 6601 Sunndalsøra, Norway \\ ${ }^{3}$ Department of Materials Science and Engineering, Norwegian University of Science and Technology, Alfred Getz vei 2B, \\ 7491 Trondheim, Norway
}

Correspondence should be addressed to Emanuela Cerri; emanuela.cerri@unipr.it

Received 1 September 2017; Accepted 4 December 2017; Published 6 February 2018

Academic Editor: Fantao Kong

Copyright (c) 2018 Maria Teresa Di Giovanni et al. This is an open access article distributed under the Creative Commons Attribution License, which permits unrestricted use, distribution, and reproduction in any medium, provided the original work is properly cited.

\begin{abstract}
The present work investigates a narrow range of secondary dendrite arm spacing (SDAS), in an as-cast A356 alloy with and without copper $(\mathrm{Cu})$ additions. $\mathrm{Cu}$ was added to the base A356 alloy melt to reach the target concentration of 0.5 and 1 wt.\%. Samples were selected from 3 different positions within the cast plate, offering 30, 35, and $40 \mu \mathrm{m}$ SDAS variants. Tensile curves revealed a strong influence between the specimen cutting position and strength, with a pronounced effect in the $\mathrm{Cu}-\mathrm{containing}$ alloys. Hardness measurements did not confirm the tensile response; hence, to understand the phenomenon, microstructural features have been investigated in detail. Eutectic silicon ( $\mathrm{Si}$ ) particle equivalent diameter (ED) size decreased from the top (T) to the bottom (B) position of the cast. Eutectic Si particle surface area (A\%) was found to be denser at the B as compared to the T and simultaneously in the $\mathrm{Cu}$-containing alloy as compared to the $\mathrm{Cu}$-free reference alloy. Backscattered electron (BSE) images were employed to investigate the nature of the $\mathrm{Cu}$-rich intermetallic phases. In conclusion, electrical conductivity measurements were performed to confirm the trends observed.
\end{abstract}

\section{Introduction}

Alloy composition and cooling rate play a key role on the castability $[1,2]$ and also on the mechanical properties of aluminum-silicon cast alloys. The cooling rate controls the microstructural features of the material including the secondary dendrite arm spacing (SDAS), which is often used as a measure of the grain size of the material and thus as a measure of the mechanical response. The fraction, size, shape, and distribution of eutectic silicon particles and intermetallic phases in the aluminum matrix $[2,3]$ also give a crucial contribution in connection with microstructure optimization. Eutectic Si particles, providing inhomogeneity in the $\alpha$-Al matrix, act as the principal source of stress concentration points [4-6], and therefore, industrial castings are regularly modified by strontium ( $\mathrm{Sr}$ ) additions. Eutectic silicon particles alter their shape from needle-like to fibrous morphology obtaining a more ductile material. Among the Al-Si foundry alloys, the most commonly used are the A356 and the A357, where magnesium $(\mathrm{Mg})$ is the main alloying element due to its appreciable tendency to promote metastable precipitates under age-hardening treatment. Industries, especially in the automotive sector, are showing a growing interest in finding suitable chemical compositions for cast aluminum alloys for high temperature applications (e.g., currently diesel engine cylinder heads reach up to $250^{\circ} \mathrm{C}$ ). In this concern, the addition of copper $(\mathrm{Cu})$ to traditional $\mathrm{Al}-\mathrm{Si}-\mathrm{Mg}$ alloys has been recently 
TABLE 1: Chemical composition (wt.\%) of A356 reference alloy and Cu-containing alloys as measured by OES and their classification.

\begin{tabular}{lccccccccc}
\hline Alloy & $\mathrm{Si}$ & $\mathrm{Mg}$ & $\mathrm{Fe}$ & $\mathrm{Cu}$ & $\mathrm{Ti}$ & $\mathrm{B}$ & $\mathrm{Sr}$ & $\mathrm{Al}$ & $\mathrm{Code}$ \\
\hline A356 (reference) & 6.624 & 0.216 & 0.086 & 0.006 & 0.103 & $4.6 \mathrm{ppm}$ & $14 \mathrm{ppm}$ & $\mathrm{Bal}$. & $\mathrm{Cu} 0$ \\
$\mathrm{~A} 356+0.5$ wt.\% $\mathrm{Cu}$ & 6.587 & 0.258 & 0.082 & 0.454 & 0.105 & $5.6 \mathrm{ppm}$ & $80.8 \mathrm{ppm}$ & $\mathrm{Bal}$. & Cu0.5 \\
A356 + 1 wt.\% Cu & 6.915 & 0.262 & 0.091 & 0.983 & 0.086 & $5.6 \mathrm{ppm}$ & $74.5 \mathrm{ppm}$ & $\mathrm{Bal}$. & Cu1 \\
\hline
\end{tabular}

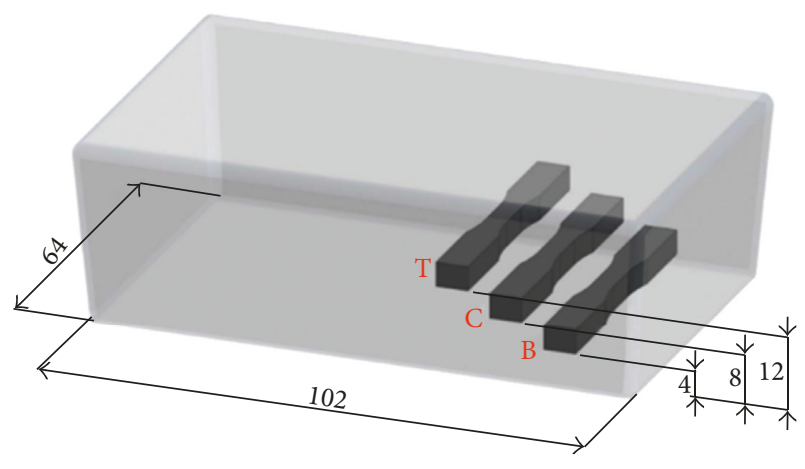

FIGURE 1: Specimen cutting position. B: bottom specimen, C: center specimen, and T: top specimen (values are given in $\mathrm{mm}$ ).

investigated [7-9]. In particular, the concomitant presence of both copper and magnesium in $\mathrm{Al}-\mathrm{Si}-\mathrm{Cu}-\mathrm{Mg}$ alloys should in fact enable the precipitation of more stable $\mathrm{Cu}$-based intermetallic precipitates at higher temperatures, leading to enhanced thermal stability of the T6 heat-treated alloys [10]. In addition to $\beta^{\prime}\left(\mathrm{Mg}_{2} \mathrm{Si}\right)$ and $\theta^{\prime}\left(\mathrm{Al}_{2} \mathrm{Cu}\right)$ precipitates, present in ternary $\mathrm{Al}-\mathrm{Si}-\mathrm{Mg}$ and $\mathrm{Al}-\mathrm{Si}-\mathrm{Cu}$ alloys [10-15], reinforcing compounds such as the $S^{\prime}$ phase $\left(\mathrm{Al}_{2} \mathrm{CuMg}\right)[14,16,17]$ and the Q' phase (whose general stoichiometry is $\mathrm{Al}_{5} \mathrm{Cu}_{2} \mathrm{Mg}_{8} \mathrm{Si}_{6}$ ) are found in quaternary $\mathrm{Al}-\mathrm{Si}-\mathrm{Cu}-\mathrm{Mg}$ alloys. In this context, many studies attested that improvement in strength is achieved at the expense of elongation [3,10]; others, instead, reported an increase in high-temperature strength due to the addition of $\mathrm{Cu}$ up to 0.5 wt.\%, without loss of ductility $[18,19]$. Seifeddine et al. $[2,20]$ found $\mathrm{Cu}$ and $\mathrm{Mg}$ to promote the formation of bands of coarse Si particles and to enlarge the solidification interval, increasing risk in forming shrinkage porosity, thus compromising the ductility.

Whereas the most pertinent literature focuses on the influence of a single variable on the mechanical properties of cast $\mathrm{Al}-\mathrm{Si}-\mathrm{Mg}$ alloy, the present study proposes a combined overview on the well-known A356 foundry alloy. The two aspects of SDAS and $\mathrm{Cu}$ additions were correlated in series and parallel. For a better understanding of the topic proposed, as first approach, the authors decided to investigate the A356 alloy in the as-cast condition, and future work will extend the analysis to the heat treated alloys. Samples were selected from 3 different positions in the cast, offering 30,35 , and $40 \mu \mathrm{m}$ SDAS variants. Cu was added to the cast to reach the target concentration of 0.5 and $1 \mathrm{wt} . \%$. In addition to the above mentioned issues, eutectic Si particle size and distribution were analyzed over the six different conditions, and the influence of $\mathrm{Cu}$ on the $\mathrm{Cu} / \mathrm{Mg} / \mathrm{Fe}$-rich phases were examined by scanning electron microscope (SEM) and energy dispersive X-ray spectroscopy (EDS).
TABLE 2: Characteristic temperatures for the nucleation $\left(T_{N, \alpha}\right)$ of the $\alpha$-Al phase in A356 alloys and start of main eutectic reaction $\left(T_{N, \text { eu }}\right)$.

\begin{tabular}{lccc}
\hline Code & $\begin{array}{c}\text { Cu conc. } \\
\text { wt.\% }\end{array}$ & $\begin{array}{c}T_{N, \alpha} \\
{ }^{\circ} \mathrm{C}\end{array}$ & $\begin{array}{c}T_{N, \text { eu }} \\
{ }^{\circ} \mathrm{C}\end{array}$ \\
\hline $\mathrm{Cu} 0$ & - & 621 & 578 \\
$\mathrm{Cu} 0.5$ & 0.45 & 615 & 563 \\
$\mathrm{Cu} 1$ & 0.98 & 613 & 560 \\
\hline
\end{tabular}

\section{Materials and Methods}

Commercial Sr-modified A356 alloy was melted in a boronnitride-coated clay-graphite crucible at $750^{\circ} \mathrm{C}$ and grain refined by $\mathrm{Al}-5 \mathrm{Ti}-1 \mathrm{~B}$ master alloy additions. $\mathrm{Cu}$ was added to the melt in form of pure copper grains according to the targeted nominal concentrations of 0.5 and 1 wt.\%. Molten metal was successively stirred and allowed to settle for $30 \mathrm{~min}$ to ensure complete dissolution. Alloys were then degassed with argon for 5 min just prior to being poured in a copper mold of $65 \times 103 \times 40 \mathrm{~mm}^{3}$. The dye was preheated at $50^{\circ} \mathrm{C}$ for all the casting trials. Samples from the three different melts were taken and analyzed by optical emission spectroscopy (OES). The chemical compositions of the alloys are given in Table 1.

The experimental setup for thermal analysis measurements is described as follows: a graphite crucible was preheated at $750^{\circ} \mathrm{C}$ and placed on the top of the skimmed and thoroughly stirred melt. After the temperatures of crucible and melt had reached equilibrium, samples were taken by submerging the graphite crucibles into the melt. The filled crucibles were then placed on Fiberfrax board, and a K-type thermocouple was lowered into the melt. The thermocouple tip was positioned at the center of the melt. A Campbell logger (Campbell Scientific, Inc., USA) recorded the temperature-time curve at a frequency of $50 \mathrm{~Hz}$. Prior to and after a measurement, the range of eventual thermocouple drift was checked against high-purity aluminum ( $\mathrm{Al} 5 \mathrm{~N}$ grade) assuming a solidus temperature of $660^{\circ} \mathrm{C}$.

Tensile tests were performed at room temperature, using an MTS 810 universal testing machine. The crosshead speed was $1 \mathrm{~mm} / \mathrm{min}$. The specimens, with a gauge length of $7 \mathrm{~mm}$ and cross section of $4 \mathrm{~mm} \times 4 \mathrm{~mm}$, were cut from three different positions in the ingot: at $4 \mathrm{~mm}$ from the cast bottom skin, at $8 \mathrm{~mm}$, and $12 \mathrm{~mm}$, respectively, referred as bottom (B), center (C), and top (T) (Figure 1), expecting different solidification rates. The height of the casting, restricted to the mold limitation, was ranging between $30 \mathrm{~mm}$ and $40 \mathrm{~mm}$. Stress-strain curves were obtained by attaching a knife-edge extensometer at the specimens' gauge length and the tensile properties, such as yield strength, ultimate 


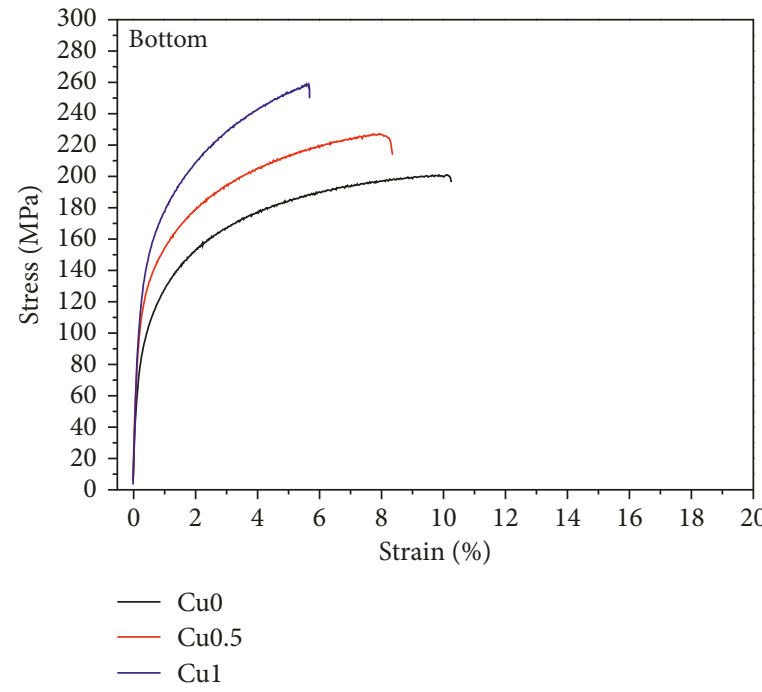

(a)

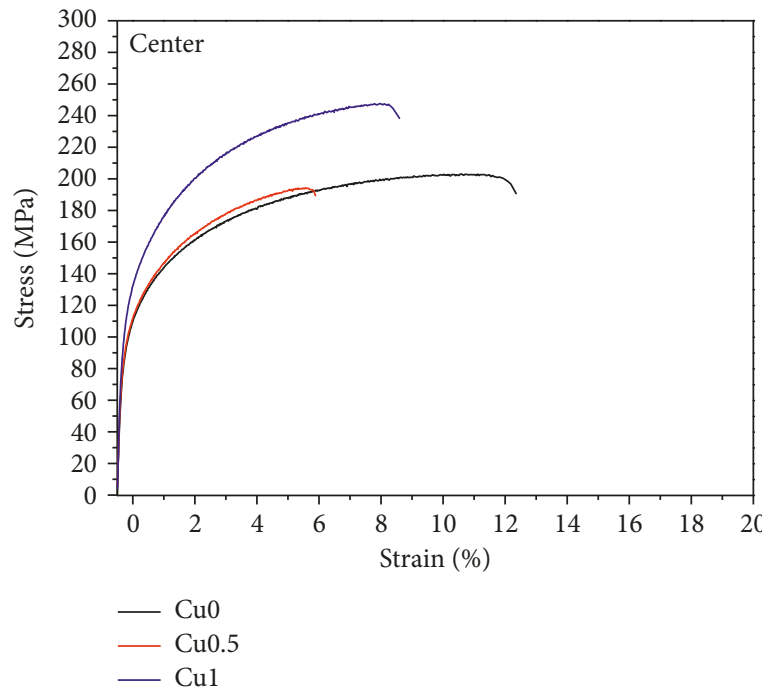

(c)

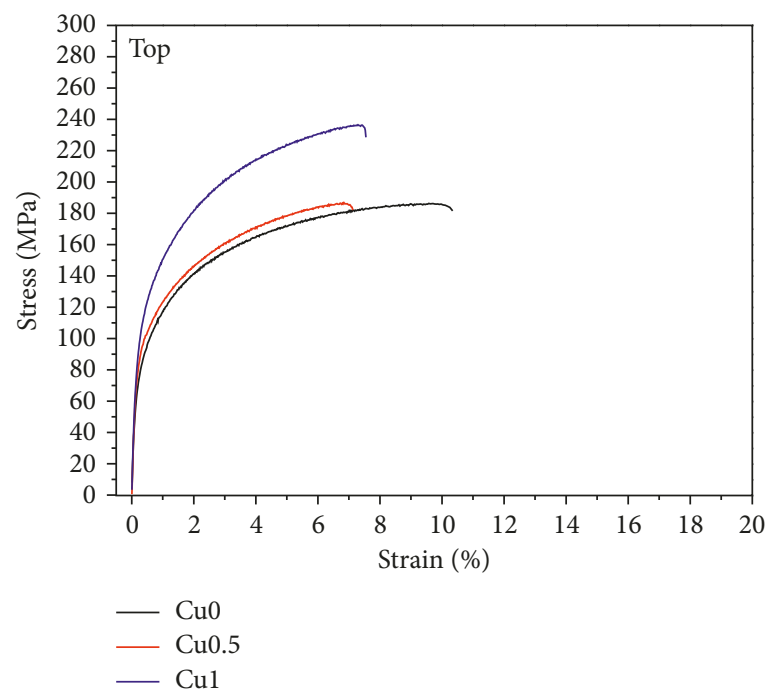

(e)

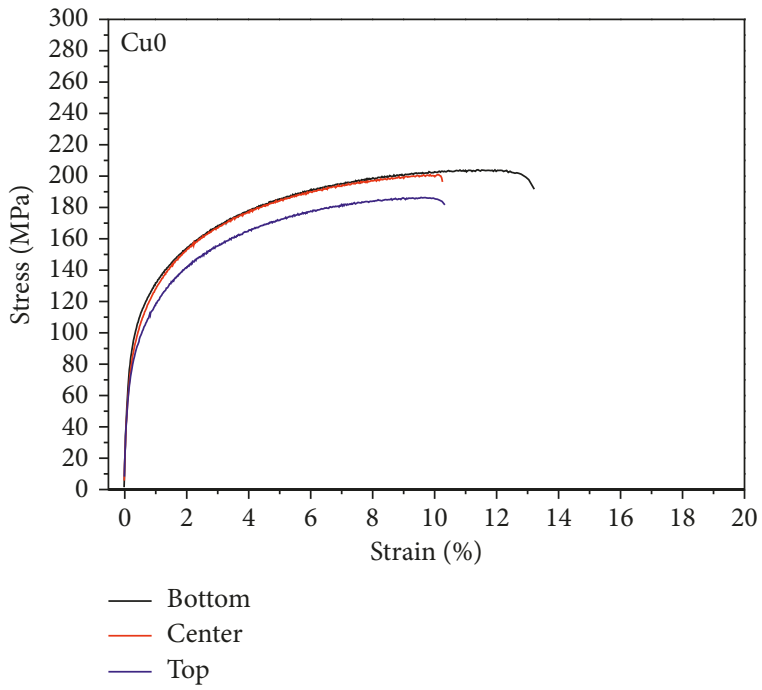

(b)

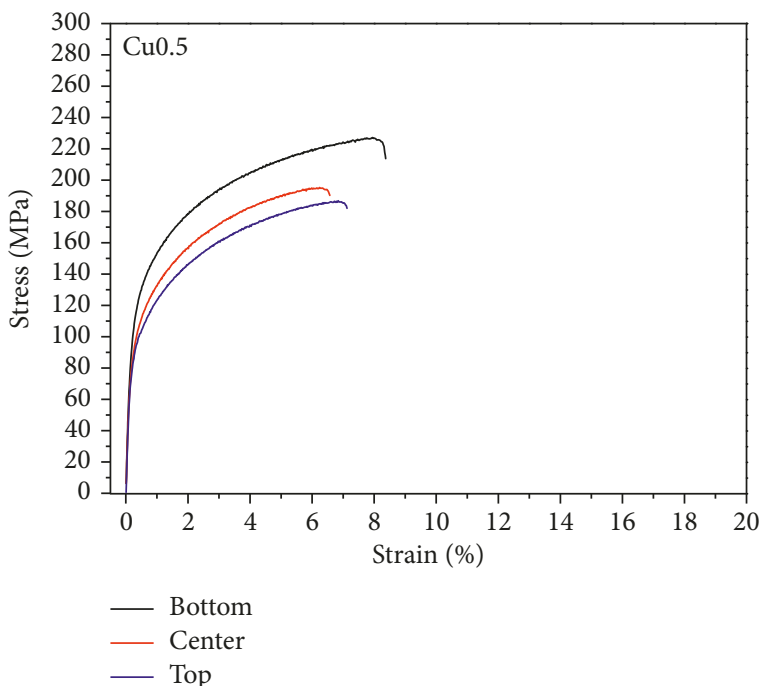

(d)

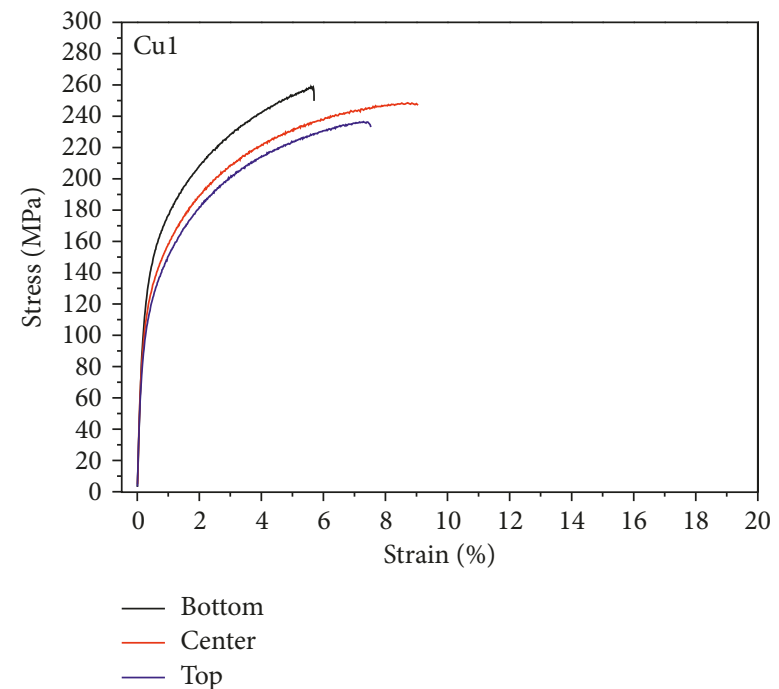

(f)

FIgURE 2: Tensile strength-strain curves of the three investigated alloys as a function of both Cu content $(\mathrm{a}, \mathrm{b}, \mathrm{c})$ and specimen cutting position (d, e, f). 


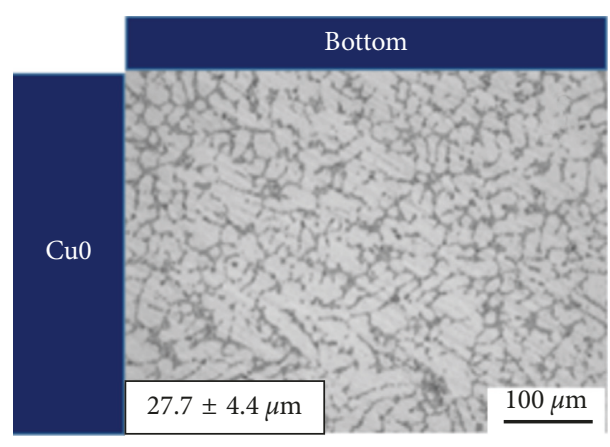

(a)

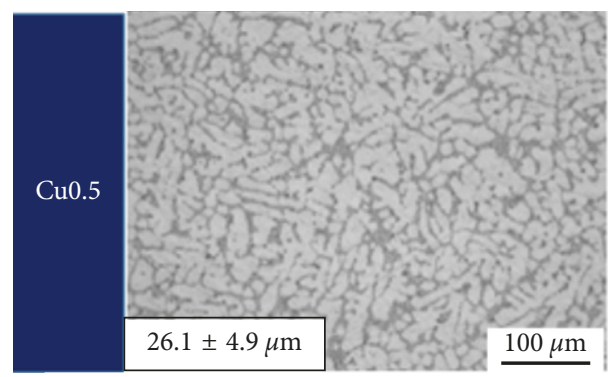

(d)

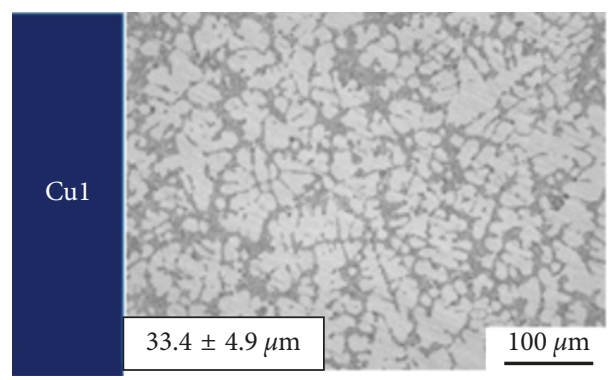

(g)

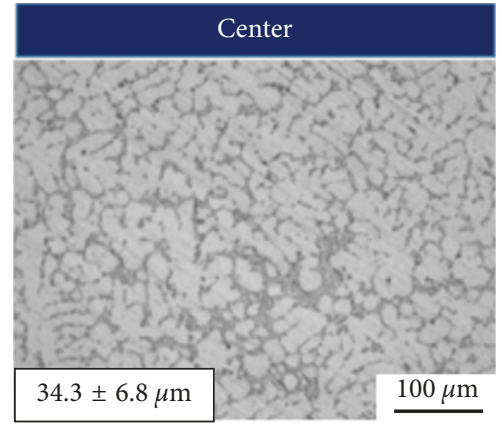

(b)

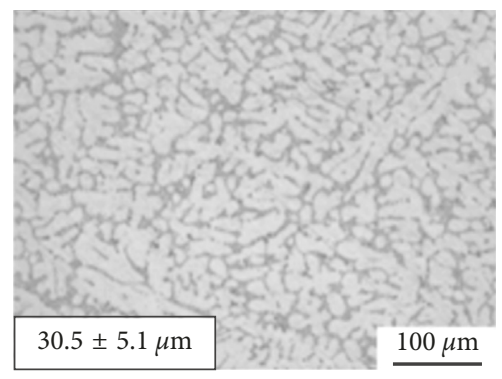

(e)

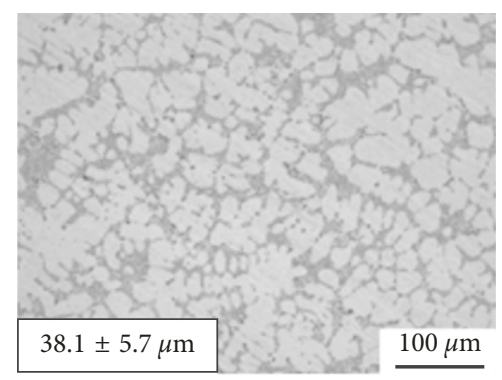

(h)

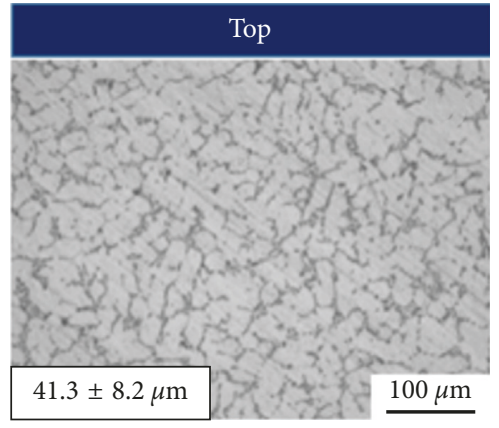

(c)

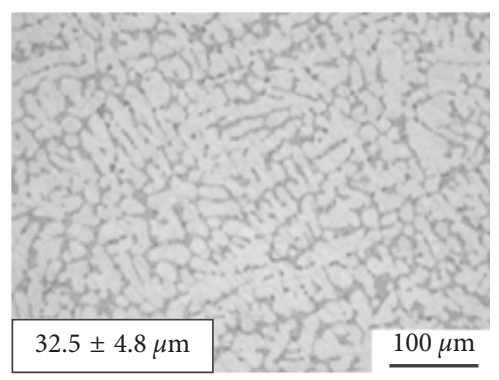

(f)

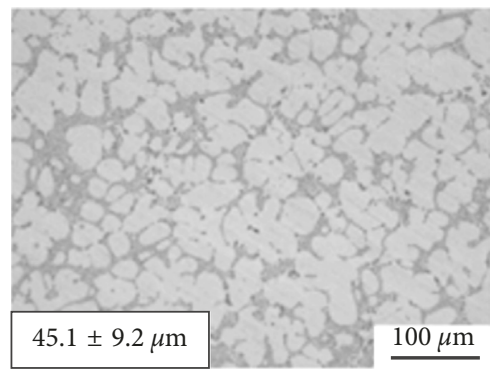

(i)

Figure 3: Optical micrographs and SDAS measurements as function of $\mathrm{Cu}$ content and specimen cutting position. Micrographs depict the microstructure of the $\mathrm{Cu}$-free alloy (a)-(c), the $0.5 \% \mathrm{Cu}$ alloy (d)-(f), and the $1 \% \mathrm{Cu}$ alloy (g)-(i) with SDAS ranging from $30 \mathrm{up}$ to $\sim 40 \mu \mathrm{m}$.

tensile strength, and percentage elongation $\left(\mathrm{Rp}_{0.2}\right.$, UTS, and $\mathrm{A} \%$, resp.), were determined.

Vickers microhardness tests (HV) were performed at the bottom, center, and top of the cast ingots at a load of $300 \mathrm{~g}$ and a dwell time of $15 \mathrm{~s}$, according to UNI EN ISO 6507 specification [21]. Further, hardness examinations were conducted by means of Rockwell hardness measurements, with a load of $60 \mathrm{kgf}$, and 1/16" ball intender (HRF), according to UNI EN ISO 6508-2 specification [22]. Electrical conductivity was measured by a Foerster Sigmatest operating at $60 \mathrm{kHz}$. Samples for microstructural investigations were cut from the tensile specimens, embedded in phenolic resin and prepared using standard grinding and polishing procedures. Microstructure analyses were performed using a LEICA DMi8 polarized light optical microscope (OM) equipped with a LASX image analysis program. SDAS measurements were performed using the line intercept method. Secondary phases were investigated with a ZEISS ULTRA 55 field emission scanning electron microscope (FE-SEM) and identified through energy dispersive X-ray spectroscopy (EDS), operated at an acceleration voltage of $20 \mathrm{kV}$.
A statistical study on the eutectic Si particle equivalent diameter (ED) and surface area (SA) was also carried out. To analyze the particles, a specific threshold was defined: pixel color ranges were restricted to the scale of light grey corresponding to eutectic Si particles. ED distributions were calculated on images detected at $1000 \mathrm{x}$ whereas representative eutectic Si particle surface area distributions over the B, C, and T zones at 200x.

\section{Results and Discussion}

3.1. Thermal Analysis. Characteristic temperatures from thermal analysis of A356 reference alloy and $\mathrm{Cu}$-containing A356 alloys are given in Table 2. The two reactions, nucleation and growth of the $\alpha$-Al phase and start of main eutectic reaction, are referred in Table 2 as $T_{N, \alpha}$ and $T_{N \text {,eu }}$, respectively. Nucleation temperature of primary aluminum dendrites $\left(T_{N, \alpha}\right)$ shifts to a lower temperature with increasing $\mathrm{Cu}$ content. According to Arnberg and Bäckerud [23] and Bäckerud et al. [24], in commercial unmodified A356 alloy, with a cooling rate of $1.1 \mathrm{~K} / \mathrm{s}$ before solidification, the 


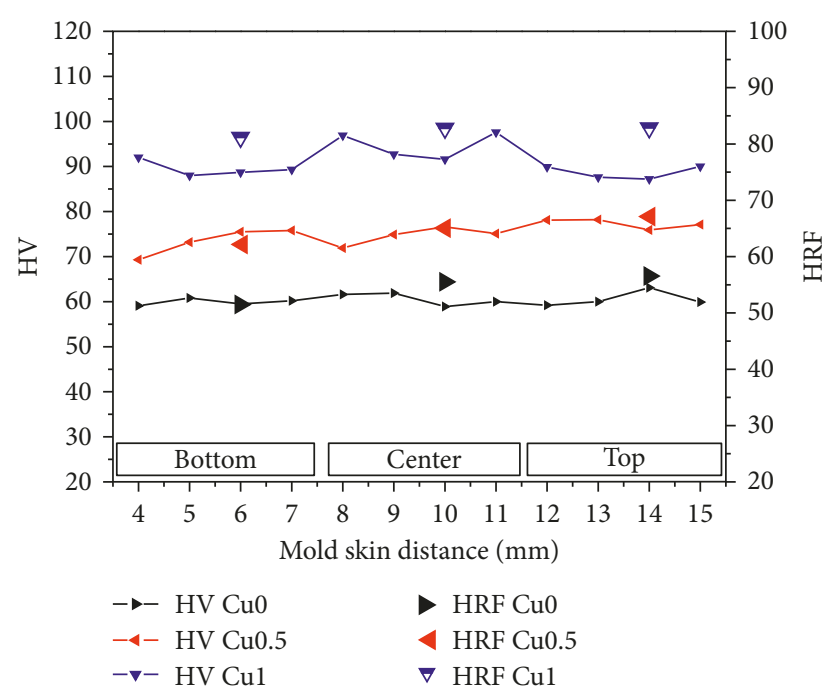

FIgURE 4: Cast ingot hardness profile. Vickers microhardness scale on the left; Rockwell hardness scale on the right.

precipitation of $\alpha-\mathrm{Al}$ starts at $610^{\circ} \mathrm{C}$. This temperature varies within the range of $608-615^{\circ} \mathrm{C}$ with different cooling rates, whereas the $\mathrm{Cu} 0, \mathrm{~A} 356$ reference alloy in this study, shows that formation and growth of primary $\alpha$-Al dendrites begins at $621^{\circ} \mathrm{C}$. The shift observed, is mainly imputable to the presence of $\mathrm{TiB}_{2}$, well known as excellent grain refiner for this class of material [25]. When it comes to $\mathrm{Cu}$-rich variants, the $\alpha$ - $\mathrm{Al}$ dendritic networks in the $\mathrm{Cu} 0.5$ and $\mathrm{Cul} \mathrm{A} 356$ alloys start to grow at the temperatures of $615^{\circ} \mathrm{C}$ and $613^{\circ} \mathrm{C}$, respectively. The results agree with those presented by Mackay and Gruzleski [26] suggesting for an A356 alloy with high $\mathrm{Cu}$ content $(0.61$ wt.\%) the formation and growth of primary $\alpha$-Al dendrites at $612^{\circ} \mathrm{C}$. Approaching the eutectic transformation, we can observe similar trends, and thus, as expected, the eutectic transformation of $\mathrm{Cu} 0$ variant occurs at $578 \pm 1^{\circ} \mathrm{C}$. The influence of $\mathrm{Cu}$ is more prominent in this reaction as the $\mathrm{Cu} 0.5$ and Cul $T_{\mathrm{Neu}}$ decrease sensibly by $18^{\circ} \mathrm{C}$. Nevertheless, the higher $\mathrm{Sr}$ content in the $\mathrm{Cu}$-containing alloys, resulted after the casting, prevents us correlate the phenomenon solely to the $\mathrm{Cu}$ content. According to Zeren et al. [27], lower eutectic temperatures could be due to the formation of quaternary eutectic phases.

3.2. Mechanical Properties. Figure 2 summarizes room temperature tensile curves of the three alloys as a function of $\mathrm{Cu}$ content (Figures 2(a)-2(c)) and specimen cutting position (Figures 2(d)-2(f)). The curves a, b, and c clearly evidence improvement in strength with increasing $\mathrm{Cu}$ content, for the three B, C, and T specimens. In parallel, the tendency showed by curves $\mathrm{d}$, e, and $\mathrm{f}$ in Figure 3 revealed how the specimen cutting position (hence, solidification rate and microstructure) strongly influences the mechanical properties leading to an enhancement in strength by approximately $10 \%$ and $20 \%$ moving from the top to the bottom in the cast for the $\mathrm{Cu}$-free and the $\mathrm{Cu}$-containing alloys, respectively. Comparing curves $\mathrm{b}, \mathrm{d}$, and $\mathrm{f}$ in Figure 2, the elongation (A\%) decreases with increasing $\mathrm{Cu}$ content. Although it is not straight forward to compare elongations to different studies having different casting conditions, the $\mathrm{Cu} 0.5$ and $\mathrm{Cu} 1$ alloys show ductility values ranging between $6 \%$ and $9 \%$, well above the average value found in the literature [28]. The two phenomena might be related to the solidification mechanism and/or microstructural features. In this light, both these aspects will be investigated. A convenient and widely used measure of the effect of solidification conditions on dendrite structure is the secondary dendrite arm spacing (SDAS). The SDAS, which is the linear distance between two secondary aluminum dendrites (arms), was determined via the mean linear intercept (MLI) method. Figure 3 shows how cooling conditions are strongly related to specimen cutting position, even though the region of interest is restricted to a distance of $12 \mathrm{~mm}$ (Figure 1). SDAS measurements obtained from top specimens evidenced an increase by $50 \%, 35 \%$, and $25 \%$ for the $\mathrm{Cu} 0, \mathrm{Cu} 1$, and $\mathrm{Cu} 0.5$ alloys, respectively, as compared to the bottom specimens. SDAS values obtained from $B, C$, and $T$ specimens of the three considered alloys could be pooled with some approximation into three main classes offering nominal values of $30 \mu \mathrm{m}$, $35 \mu \mathrm{m}$, and $40 \mu \mathrm{m}$, respectively. It is worth mentioning that the higher content of both $\mathrm{Ti}_{2} \mathrm{~B}$ and $\mathrm{Sr}$ wt.\% resulting after the casting in the $\mathrm{Cu} 0.5$ alloy might justify the lowest SDAS values in the $\mathrm{Cu} 0.5$ alloy, as compared to both $\mathrm{Cu} 0$ and $\mathrm{Cu} 1$ alloys. Results are consistent with material tensile response observed in Figure 2.

To further address the influences of both $\mathrm{Cu}$ contents and cooling rates on the alloy's mechanical response, hardness measurements were also conducted. Vickers microhardness (HV) and Rockwell hardness (HRF) tests were performed over samples corresponding to the bottom, center, and top of the three alloys/castings considered and are presented in Figure 4. HV and HRF measurements do not reveal a clear enhancement in hardness, moving from bottom to top, as expected with reference to the linear hardness-strength relationship reported by Tiryakioğlu et al. [29] and Di Giovanni et al. [30]. Cu content, on the other hand, exerts a prominent influence in increasing the hardness response of this alloy from $60 \mathrm{HV}$ to $90 \mathrm{HV}$ in $\mathrm{Cu} 0$ and $\mathrm{Cu} 1$, respectively. At this point, the variation in tensile properties resulting from a comparison of $B$ and T samples (Figures 2(b), 2(d), and 2(f)) has been interpreted through SDAS measurements (Figure 3), and the $10 \mu \mathrm{m}$ shift, albeit its impressive effect on a small scale $(12 \mathrm{~mm})$ seems not to be the sole cause behind the tensile behavior. In summary, both the HV and the HRF measures appeared to be in evident contrast to the tensile trends.

3.3. Microstructural Investigation. In order to deeply understand how the strength is correlated to the hardness, microstructural features were investigated and, in particular, eutectic Si particle equivalent diameter distribution and eutectic Si particle \% area values have been presented in Figure 5. The distribution histograms, obtained using chi-square goodness-of-fit test, have been plotted for representative alloys which encompass reference $(\mathrm{Cu} 0)$ and $1 \mathrm{wt} . \% \mathrm{Cu}$-containing (Cu1) alloys for the 


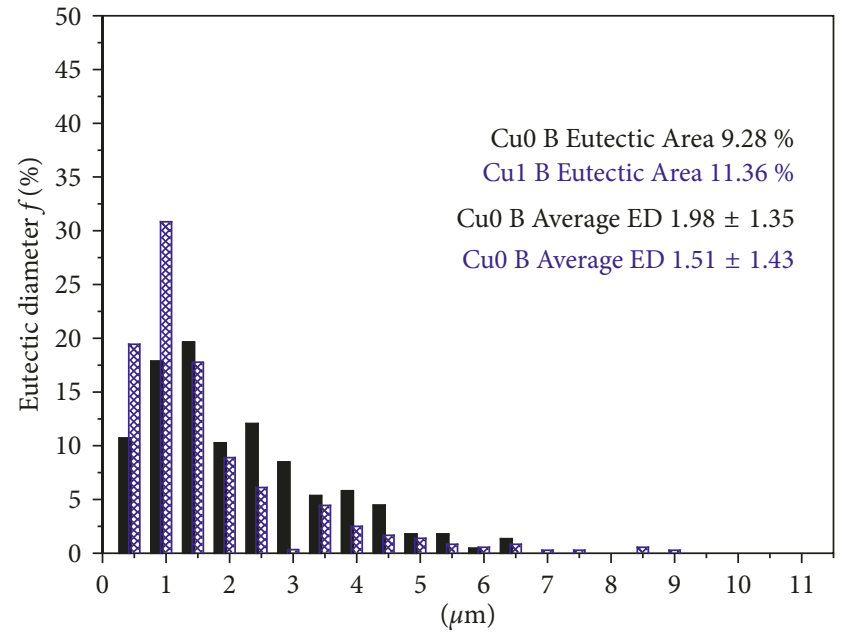

$\mathrm{Cu} 0$ Bottom Cul Bottom

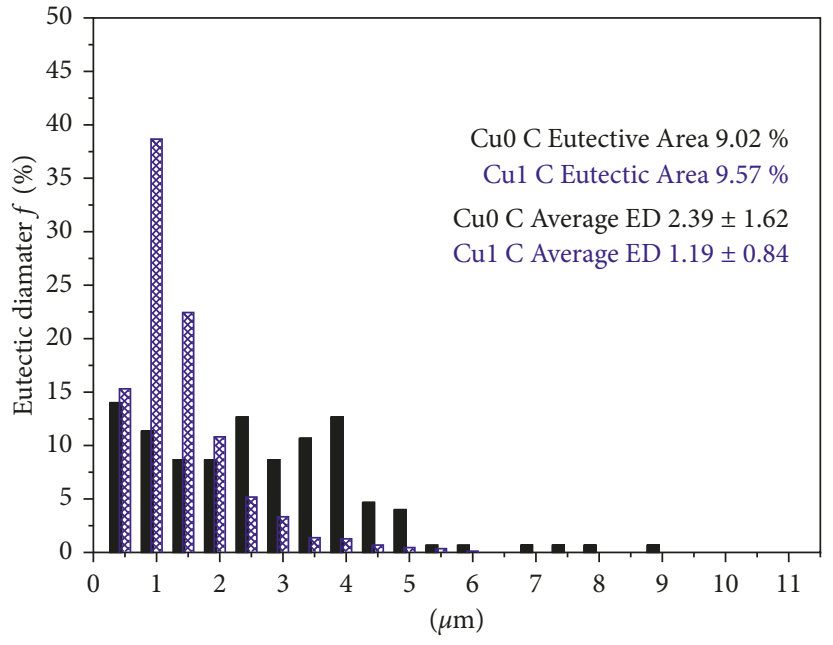

$\mathrm{Cu} 0$ Center Cul Center

(a)

(b)

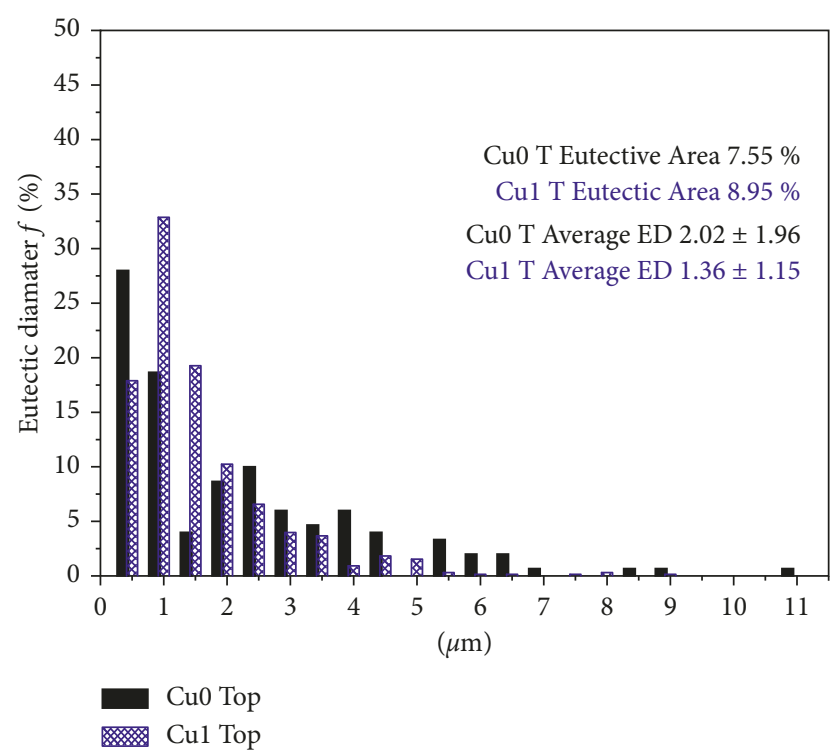

(c)

Figure 5: Distribution of the eutectic Si particles' equivalent diameter. Comparison between $\mathrm{Cu}$-free and $\mathrm{Cu}$-containing alloys (1 wt.\% Cu) in the three bottom (a), center (b), and specimen (c) cutting positions.

three bottom, center, and top specimen cutting positions. For the sake of clarity, average ED and standard deviation values were also presented. Cu0's equivalent diameter (ED) distributions show a flatter tendency if compared to $\mathrm{Cu} 1$ cases, with bottom histograms offering average ED values of $1.98 \pm 1.35$ and $1.51 \pm 1.43$, center histograms offering average ED values of $2.39 \pm 1.62$ and $1.19 \pm 0.84$, and top histograms offering average ED values of $2.02 \pm$ 1.96 and $1.36 \pm 1.15$. The shift observed in the eutectic nucleation temperature, assessing $\mathrm{Cu0}$ ' and $\mathrm{Cu} 1^{\prime} T_{N \text {,eu, }}$ respectively, to $578^{\circ} \mathrm{C}$ and to $560^{\circ} \mathrm{C}$ (Table 2), is believed to rule the eutectic Si particle size distribution. It is worth considering that Sr modification strongly affects the eutectic Si particle dimension [31] and together with the $\mathrm{Cu}$ content contributes to depress the eutectic reaction. Hence, the higher Sr content of 75-80 ppm resulted after the casting in the $\mathrm{Cu}$-containing alloys (Table 1) prevents us to address the decreasing eutectic Si particle size phenomenon, indicated by the distributions in Figure 5, to the $\mathrm{Cu}$ addition. On the other hand, frequency differences, longitudinally across the different positions (Figures 5(a)-5(c)), did not indicate any specific trends, suggesting no correlation between the eutectic Si particle ED and the specimen cutting position. Focusing on the macroscale (20x Leica DMi8 objective lens), eutectic Si particle surface area has been identified over the three interested zones: B, C, and T. Measurements show eutectic Si particle surface area $(\mathrm{A} \%)$ to be denser at the bottom as 

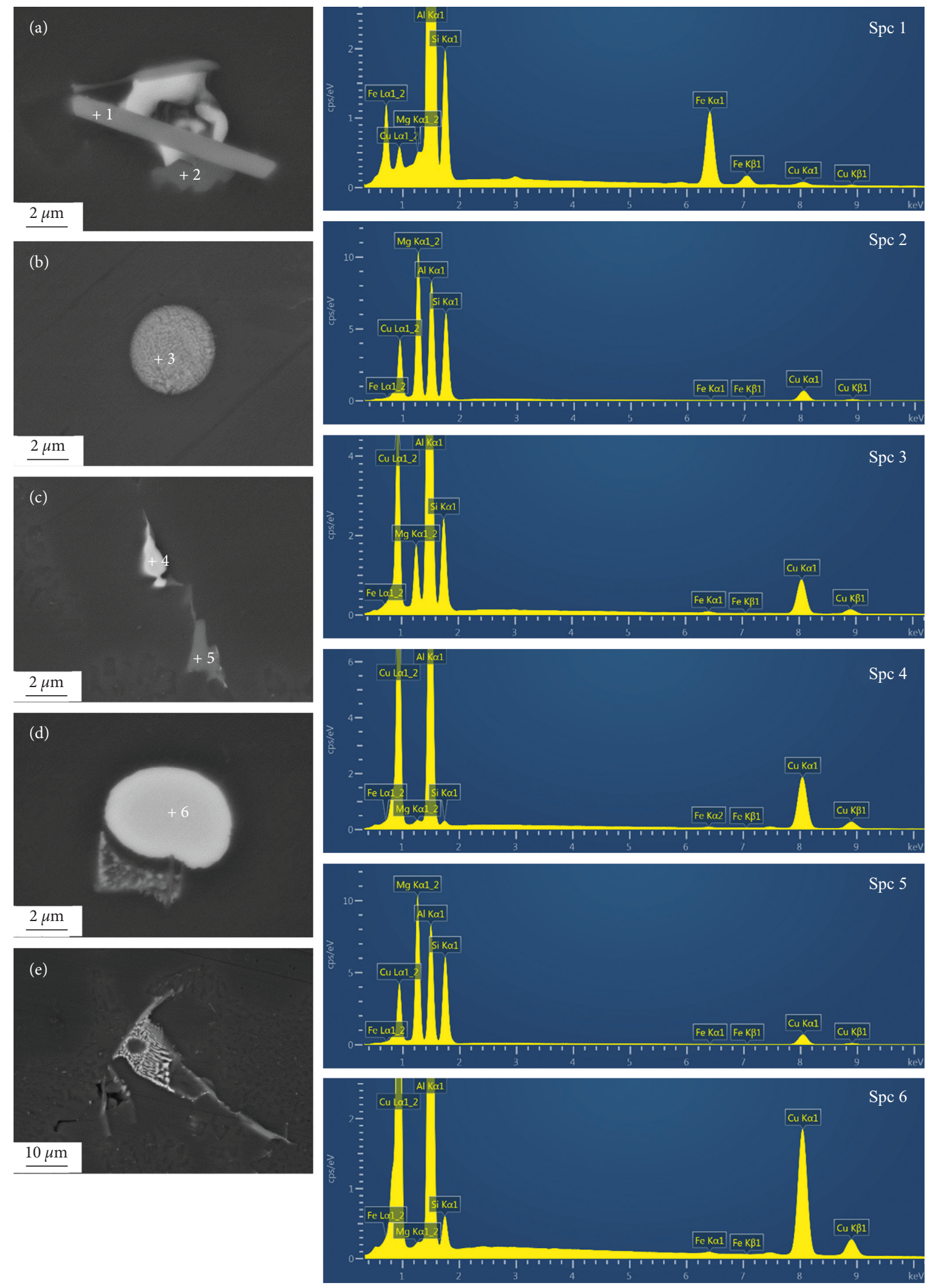

FIGURE 6: BSE images of some intermetallic phases detected in the $\mathrm{Cu}$-containing alloy (Cu1), in the as-cast condition. EDS measurements indicate the nature of the intermetallic compound as $\mathrm{Al}_{2} \mathrm{Cu}, \beta-\mathrm{Al}_{5} \mathrm{FeSi}$, and $\mathrm{Cu} / \mathrm{Mg}$ bearing intermetallics. 
TABLE 3: Composition of the located intermetallic phases as measured by semiquantitative EDS.

\begin{tabular}{lcccccc}
\hline & & \multicolumn{2}{c}{ Composition in (at. \%) } & & \\
Spectrum & Phase & $\mathrm{Al}$ & $\mathrm{Si}$ & $\mathrm{Cu}$ & $\mathrm{Mg}$ & \multicolumn{2}{c}{$\mathrm{Fe}$} \\
\hline 1 & $\beta-\mathrm{Al}_{5} \mathrm{FeSi}$ & 81.7 & 10.3 & 0.5 & 7.3 \\
2 & $\mathrm{Q}-\mathrm{Al}_{5} \mathrm{Mg}_{8} \mathrm{Si}_{6} \mathrm{Cu}_{2}$ & 59.8 & 17.3 & 5.2 & 0.2 & 17.7 \\
3 & $\mathrm{Al}-\mathrm{Q}-\theta$ & 67.5 & 14.2 & 11.5 & 6.5 & 0.1 \\
4 & $\theta-\mathrm{Al}_{2} \mathrm{Cu}$ & 72.5 & 1.2 & 25.6 & 0.6 \\
5 & $\mathrm{Q}-\mathrm{Al}_{5} \mathrm{Mg}_{8} \mathrm{Si}_{6} \mathrm{Cu}_{2}$ & 33.1 & 27.2 & 7.7 & 32 \\
6 & $\theta-\mathrm{Al}_{2} \mathrm{Cu}$ & 67.5 & 3.8 & 28.3 & 0.1 \\
\hline
\end{tabular}

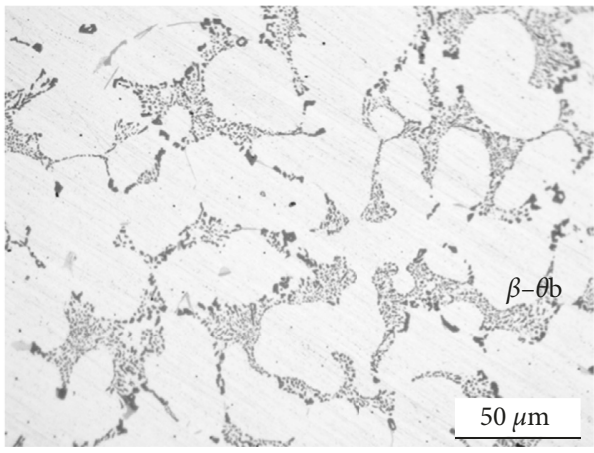

(a)

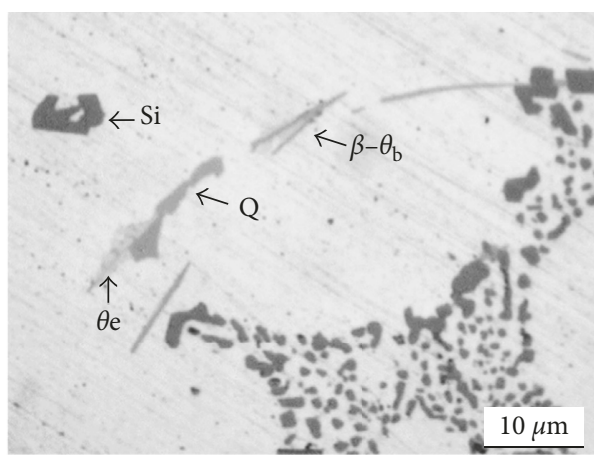

(c)

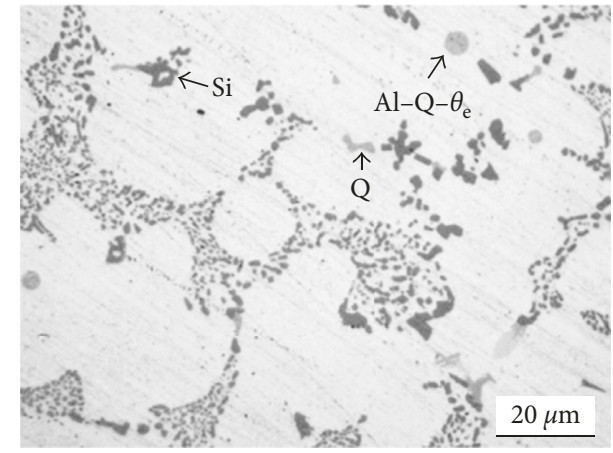

(b)

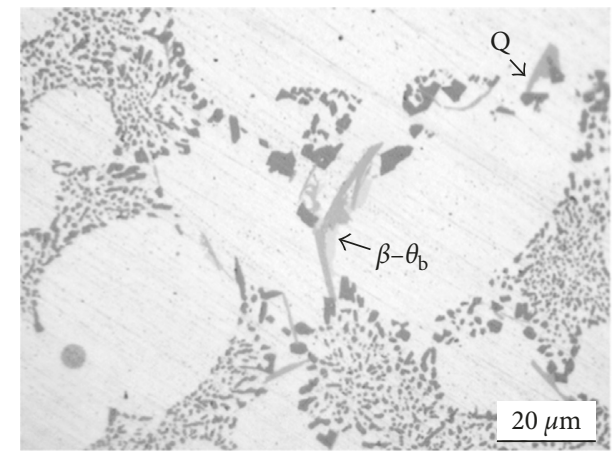

(d)

FiguRE 7: Optical micrographs of the $\mathrm{Cu}$-containing alloy $(\mathrm{Cu} 1)$ where Fe-rich and $\mathrm{Mg}$-/Cu-bearing phases are found as companion to the $\mathrm{Si}$ eutectic.

compared to the top and, in parallel, show eutectic Si particles to be denser in the $\mathrm{Cu}$-containing alloy.

Representative backscattered electron (BSE) images and EDS spectra of the $\mathrm{Cu}$-containing phases are presented in Figure 6. Composition of the detected intermetallic phases as measured by semiquantitative ESD is labelled in Table 3. For the sake of clarification, only the as-cast Cul BSE micrographs are reported. Since heavy elements (high atomic number) backscatter electrons more strongly than light elements (low atomic number), they appear brighter in the image. Consequently, BSE micrographs were used to detect contrast between areas with different chemical compositions. As a matter of fact, $\mathrm{Cu}$-bearing phases appear in white and are found in different morphologies, resulting after $\mathrm{Al}-\mathrm{Si}$ eutectic reaction. The $\theta-\mathrm{Al}_{2} \mathrm{Cu}$ phases, with the higher $\mathrm{Cu}$ content $\sim 30$ at. $\%$, are presented in both blocky ( +4 " in
Figure 6(c); " +6 " in Figure 6(d)) and eutectic shapes (Figure 6(e)). They are usually associated with $\beta-\mathrm{Al}_{5} \mathrm{FeSi}$ plates or coarse eutectic Si particles, as result of their formation in the last stage of solidification. Other high $\mathrm{Cu}$ content particles have been identified as the quaternary $\mathrm{Q}$ phase, $\mathrm{Al}_{5} \mathrm{Mg}_{8} \mathrm{Si}_{6} \mathrm{Cu}_{2}$. Because of the small size of these particles, it is not straight forward to determine by EDS the exact stoichiometry of the $Q$ phase. The results, however, were consistent with the most widely accepted composition [32-34]. Most of these phases are observed in the form of isolated polygonal particles ( " +5 ” in Figure 6(c)) and the rest forming a fine rounded/spherical ternary eutectic feature together with the $\theta$ phase $("+3$ " in Figure 6(b)) as also reported by Han et al. [35]. In addition, light microscopy pictures of intermetallic phase distribution in the matrix are shown in Figure 7. Macro overview of the $\mathrm{Cu} 1$ as-cast microstructure is presented in 


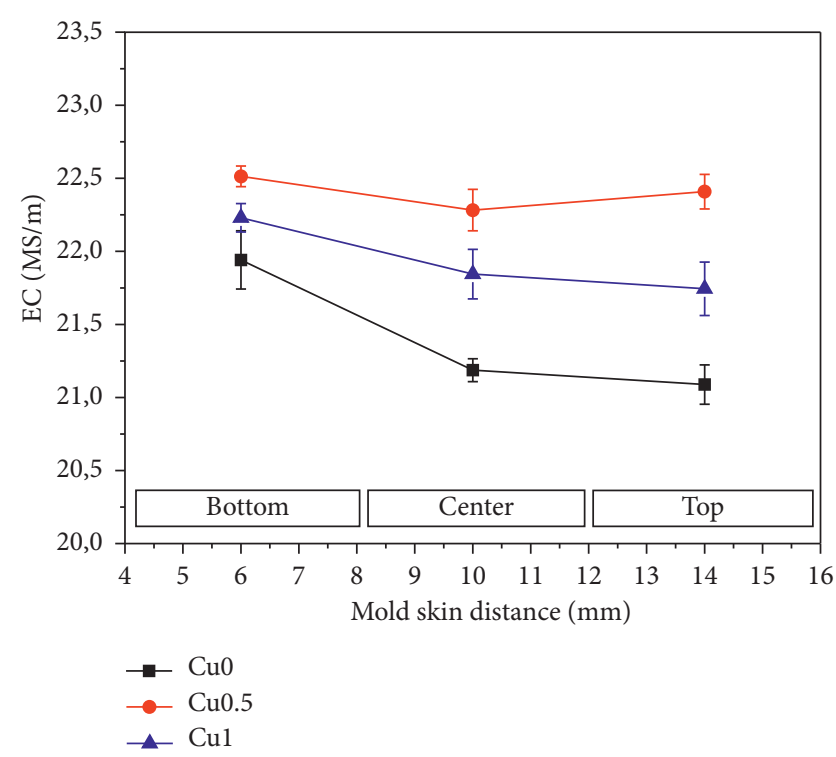

Figure 8: $\mathrm{Cu} 0, \mathrm{Cu} 0.5$, and $\mathrm{Cu} 1$ electrical conductivity measurements over the three investigate positions: bottom, center, and top.

Figure 7(a). The rounded eutectic phases, indicated as Al-Q- $\theta$ (Figures $7(\mathrm{~b})$ and $7(\mathrm{c})$ ), together with both the eutectic and the blocky forms of the $\mathrm{Al}_{2} \mathrm{Cu}$ phases were observed in the interdendritic channels, or combined with the $\beta$-phase (Figures 7(c) and 7(d)).

3.4. Electrical Conductivity Measurements. Figure 8 shows the electrical conductivity (EC) evolutions of the three alloys as a function of the specimen cutting position: bottom, center, and top. In general, the addition of any alloying elements into Al reduces the electrical conductivity. Hence, increasing the $\mathrm{Cu}$ content, it is expected that a corresponding decrease in electrical conductivity will occur as more solute atoms go into solid solution [36-39]. Cu0's EC response appears in contrast to the tendency predicted. The phenomenon could be explained by the low Sr content resulting after the casting (Table 1). According to Mulazimoglu [40], the $\mathrm{EC}$ of $\mathrm{Al}-\mathrm{Mg}-\mathrm{Si}$ alloy is significantly affected by changes in morphology of the eutectic silicon; in particular, it has been found that the electrons flow more easily through finer eutectic silicon in the modified alloy than in the coarse acicular silicon present in the unmodified alloys. Besides this, with reference to the $\mathrm{Cu} 0.5$ and $\mathrm{Cu} 1$ alloys, it can be observed that the amount of copper solute retained in the matrix, decreasing the mean free path of electrons, plays a significant role in controlling the electrical conductivity. Considering the global trend as a function of the mold skin distance, EC values (averaged over 8 measures) highlight a slight but definite decrease moving from the bottom to the top sample, indicating a higher content of solute atoms in the top $\alpha$-matrix as compared with the bottom. The present data appears to be the link that joins the above discussed controversy between the tensile and hardness response. In details, assuming that the presence of eutectic Si particles is associated with the presence of $\mathrm{Si}-/ \mathrm{Mg}$-/Cu-rich intermetallics, the higher the Si eutectic content (Figure 5) the higher the intermetallics content. As a result, the bottom, richer in these $\mathrm{Si} / \mathrm{Mg}$-/Cu-bearing compounds, achieved the highest tensile strengthening as compared to the center and top (Figures 2(b), 2(d), and 2(f)). In parallel, $\alpha$-Al matrix, impoverished by metastable solute $\mathrm{Si}$, $\mathrm{Mg}$, and $\mathrm{Cu}$ atoms, showed increasing hardness trends moving from bottom to top (Figure 4). The entire discussion is supported by EC results that assessed higher content of solute metastable elements in the top as compared to the bottom.

\section{Conclusions}

In this work, 3 different sites within the cast plate, offering a narrow range of correspondent secondary dendrites arm spacing (SDAS) values, were compared. The investigation was performed on as-cast A356 alloy with and without copper $(\mathrm{Cu})$ additions. Based on the results, the following conclusions can be summarized:

(1) Stress-strain curves clearly show improvement in strength with increasing $\mathrm{Cu}$ content, for the three B (bottom), C (center), and T (top) specimens, without significant reduction of elongation. In parallel, tensile curves reveal how the specimen cutting position influences the mechanical properties leading to an enhancement in strength by approximately $10 \%$ and $20 \%$ for the $\mathrm{Cu}$-free and the $\mathrm{Cu}$-containing alloys, respectively, moving from the top to the bottom.

(2) B, C, and T's SDAS values for the three Cu0 (reference), $\mathrm{Cu} 0.5$, and $\mathrm{Cu} 1$ alloy variants range between 30, 35, and $40 \mu \mathrm{m}$, respectively. The $10 \mu \mathrm{m}$ shift, albeit its impressive effect on a small scale $(12 \mathrm{~mm})$, seems not to be the sole cause behind the tensile behavior.

(3) $\mathrm{Cu}$ content exerts a prominent influence in increasing the hardness response of this alloy. In addition, a slight increment in hardness, moving from the bottom sample to the top sample, was observed to be in contrast with the material tensile response.

(4) Frequency differences across the different positions did not indicate any specific trends, suggesting no correlation between the eutectic Si particle ED and the specimen cutting position and an overall decrease in the Si particle ED size moving from the top to the bottom position. Measurements also revealed $\mathrm{Si}$ particle surface area $(\mathrm{A} \%)$ to be denser in the bottom samples compared to the top samples and, in parallel, showed $\mathrm{Si}$ particles to be denser in the $\mathrm{Cu}$ containing alloy.

(5) $\theta-\mathrm{Al}_{2} \mathrm{Cu}$ phases are observed in both blocky and eutectic shapes, usually associated with $\beta$ - $\mathrm{Al}_{5} \mathrm{FeSi}$ plates or coarse eutectic Si particles, as result of the last stage of solidification. Other high $\mathrm{Cu}$ content particles have been identified as the quaternary $\mathrm{Q}$ phase, $\mathrm{Al}_{5} \mathrm{Mg}_{8} \mathrm{Si}_{6} \mathrm{Cu}_{2}$. In addition, rounded eutectic phases, indicated as Al-Q- $\theta$, are found along the interdendritic regions. 
(6) The bottom samples, richer in Si particles and $\mathrm{Si}$-/Mg-/Cu-bearing compounds, offer the highest tensile strength and the lowest hardness. In line with these findings, electrical conductivity (EC) values decrease moving from the bottom to top position, indicating a higher content of solute atoms in the $\alpha$-matrix of the top samples as compared to the $\alpha$-matrix of the bottom samples.

\section{Conflicts of Interest}

The authors declare that there are no conflicts of interest.

\section{References}

[1] M. Di Sabatino and L. Arnberg, "Castability of aluminium alloys," Transactions of the Indian Institute of Metals, vol. 62, no. 4-5, pp. 321-325, 2009.

[2] S. Seifeddine, E. Sjölander, and T. Bogdanoff, "On the role of copper and cooling rates on the microstructure, defect formations and mechanical properties of Al-Si-Mg alloys," Materials Sciences and Applications, vol. 4, no. 3, pp. 171-178, 2013.

[3] S. G. Shabestari and H. Moemeni, "Effect of copper and solidification conditions on the microstructure and mechanical properties of Al-Si-Mg alloys," Journal of Materials Processing Technology, vol. 153-154, pp. 193-198, 2004.

[4] Q. G. Wang, C. H. Caceres, and J. R. Griffiths, "Damage by eutectic particle cracking in aluminum casting alloys A356/357," Metallurgical and Materials Transactions A, vol. 34, no. 12, pp. 2901-2912, 2003.

[5] I. Fadavi, A. Boostani, and S. Tamanthas, "Fracture behavior of thixoformed A356 alloy produced by SIMA process," Journal of Alloys and Compounds, vol. 481, no. 1-2, pp. 220-227, 2009.

[6] C. Caceres, I. L. Svensson, and J. Taylor, "Strength-ductility behaviour of Al-Si-Cu-Mg casting alloys in T6 temper," International Journal of Cast Metals Research, vol. 15, no. 5, pp. 531-543, 2003.

[7] S. Seifeddine and I. L. Svensson, "The effect of cooling conditions and variation of alloying elements on the microstructural and mechanical properties of Al-7\%Si cast alloys," Giessereiforschung, vol. 58, no. 3, pp. 50-54, 2006.

[8] A. R. Farkoosh and M. Pekguleryuz, "Enhanced mechanical properties of an $\mathrm{Al}-\mathrm{Si}-\mathrm{Cu}-\mathrm{Mg}$ alloy at $300^{\circ} \mathrm{C}$ : effects of $\mathrm{Mg}$ and the Q-precipitate phase," Materials Science and Engineering: A, vol. 621, pp. 277-286, 2015.

[9] A. R. Farkoosh, M. Javidani, M. Hoseini, D. Larouche, and M. Pekguleryuz, "Phase formation in as-solidified and heat-treated $\mathrm{Al}-\mathrm{Si}-\mathrm{Cu}-\mathrm{Mg}-\mathrm{Ni}$ alloys: thermodynamic assessment and experimental investigation for alloy design," Journal of Alloys and Compounds, vol. 551, pp. 596-606, 2013.

[10] J. Man, L. Jing, and S. G. Jie, "The effects of $\mathrm{Cu}$ addition on the microstructure and thermal stability of an Al-Mg-Si alloy," Journal of Alloys and Compounds, vol. 437, no. 1-2, pp. 146150, 2007.

[11] M. Murayama, K. Hono, M. Saga, and M. Kikuchi, "Atom probe studies on the early stages of precipitation in Al-Mg-Si alloys," Materials Science and Engineering: A, vol. 250, no. 1, pp. 127-132, 1998.
[12] L. Zhen, W. Fei, S. Kang, and H. King, "Precipitation behaviour of Al-Mg-Si alloys with high silicon content," Journal of Materials Science, vol. 32, no. 7, pp. 1895-1902, 1997.

[13] W. F. Miao and D. E. Laughlin, "Precipitation hardening in aluminum alloy 6022," Scripta Materialia, vol. 40, no. 7 , pp. 873-878, 1999.

[14] D. G. Eskin, "Decomposition of supersaturated solid solutions in Al-Cu-Mg-Si alloys," Journal of Materials Science, vol. 38, pp. 279-290, 2003.

[15] S. K. Son, M. Takeda, M. Mitome, Y. Bando, and T. Endo, "Precipitation behavior of an Al-Cu alloy during isothermal aging at low temperatures," Materials Letters, vol. 59, no. 6, pp. 629-632, 2005.

[16] S. C. Wang, M. J. Starink, and N. Gao, "Precipitation hardening in Al-Cu-Mg alloys revisited," Scripta Materialia, vol. 54, no. 2, pp. 287-291, 2006.

[17] P. Ratchev, B. Verlinden, P. De Smet, and P. Van Houtte, "Effect of cooling rate and predeformation on the precipitation hardening of an Al-4.2wt.\%Mg-0.6wt.\%Cu alloy," Scripta Materialia, vol. 38, no. 8, pp. 1195-1201, 1998.

[18] F. Feikus, "Optimization of Al-Si cast alloys for cylinder head application," AFS Transactions, vol. 106, pp. 225-223, 1998.

[19] L. Heusler, F. J. Feikus, and M. O. Otte, "Alloy and casting process optimization for engine block application," AFS Transactions, vol. 109, pp. 215-223, 2001.

[20] A. L. Dons, G. Heiberg, J. Voje, J. S. Maeland, J. O. Loland, and A. Prestmo, "On the effect of additions of $\mathrm{Cu}$ and $\mathrm{Mg}$ on the ductility of AlSi foundry alloys cast with a cooling rate of approximately $3 \mathrm{~K} / \mathrm{s}$," Materials Science and Engineering: A, vol. 413, pp. 561-566, 2005.

[21] EN ISO 6507-1,2,3, "Metallic materials-Vickers hardness testPart 1: Test method, Part 2: Verification of testing machines, Part 3: Calibration of reference blocks," 1997, 2nd edition.

[22] EN ISO 6508-1,2,3, "Metallic materials-Rockwell hardness test-Part 1: Test method (scales A, B, C, D, E, F, G, H, K, N, T), Part 2: Verification and calibration of testing machines (scales A, B, C, D, E, F, G, H, K, N, T), Part 3: Calibration of reference blocks (scales A, B, C, D, E, F, G, H, K, N, T)," 2005, 2nd edition.

[23] L. Arnberg and L. Bäckerud, Solidification Characteristics of Aluminum Alloys, Dendrite Coherency, vol. 3, Des Plaines, IL, USA, 1996.

[24] L. Bäckerud, G. Chai, and J. Tamminen, Solidification Characteristic of Aluminum Alloys, Foundry Alloys, AFS/SkanAluminium, vol. 2, Stockholm, Sweden, 1990.

[25] H. T. Lu, L.C. Wang, and S. K. Kung, "Grain Refining in A356 Alloys," Journal of the Chinese Medical Association, vol. 29, pp. 10-18, 1981.

[26] R. I. Mackay and J. E. Gruzleski, "Quantification of magnesium in 356 alloy via thermal analysis," International Journal of Cast Metals Research, vol. 10, no. 5, pp. 255-265, 1998.

[27] M. Zeren, E. Karakulak, and S. Gümüş, "Influence of $\mathrm{Cu}$ addition on microstructure and hardness of near-eutectic Al-Si-xCu-alloys," Transactions of Nonferrous Metals Society of China, vol. 21, no. 8, pp. 1698-1702, 2011, http://akademikpersonel.kocaeli.edu.tr/zeren/sci/zeren05.09.2011_ 12.01.38sci.pdf.

[28] S. A. Kori, M. S. Prabhudev, and T. M. Chandrashekharaiah, "Studies on the microstructure and mechanical properties of A356 alloy with minor additions of copper and magnesium," Transactions of the Indian Institute of Metals, vol. 62, no. 4-5, pp. 353-356, 2009.

[29] M. Tiryakioğlu, J. S. Robinson, M. A. Salazar-Guapuriche, Y. Y. Zhao, and P. D. Eason, "Hardness-strength 
relationships in the aluminum alloy 7010," Materials Science and Engineering: A, vol. 631, pp. 196-200, 2015, http://pcwww. liv.ac.uk/ yyzhao/papers/2015_msea_al_alloy.pdf.

[30] M. T. Di Giovanni, E. Cerri, M. Merlin, D. Casari, L. Arnberg, and G. L. Garagnani, "Correlation between aging effects and high temperature mechanical properties of the unmodified A356 foundry aluminium alloy," Materials Science Forum, vol. 879, pp. 424-429, 2017.

[31] Q. G. Wang, "Plastic deformation behavior of aluminum casting alloys A356/357," Metallurgical and Materials Transactions A, vol. 34, no. 9, pp. 2707-2718, 2003.

[32] L. Lasa and J. Rodrigues-Ibabe, "Evolution of the main intermetallic phases in $\mathrm{Al}-\mathrm{Si}-\mathrm{Cu}-\mathrm{Mg}$ casting alloys during solution treatment," Journal of Materials Science, vol. 39, no. 4, pp. 1343-1355, 2004.

[33] T. Lu, J. Wu, Y. Pan, S. Tao, and Y. Chen, "Optimizing the tensile properties of $\mathrm{Al}-11 \mathrm{Si}-0.3 \mathrm{Mg}$ alloys: role of $\mathrm{Cu}$ addition," Journal of Alloys and Compounds, vol. 631, pp. 276-282, 2015.

[34] L. Ceschini, A. Morri, S. Toschi, S. Johansson, and S. Seifeddine, "Microstructural and mechanical properties characterization of heat treated and overaged cast A354 alloy with various SDAS at room and elevated temperature," Materials Science and Engineering: A, vol. 648, pp. 340-349, 2015.

[35] Y. M. Han, A. M. Samuel, F. H. Samuel, and H. W. Doty, "Dissolution of Al2Cu phase in non-modified and Sr modified 319 type alloys," International Journal of Cast Metals Research, vol. 21, no. 5, pp. 387-393, 2008.

[36] M. T. Di Giovanni, E. Cerri, T. Saito et al., "Effect of copper additions and heat treatment optimization of $\mathrm{Al}-7 \% \mathrm{Si}$ aluminum alloy," La Metallurgia Italiana, vol. 11, pp. 43-47, 2016.

[37] D. L. Zhang and L. Zheng, "The quench sensitivity of cast Al-7 wt pct Si-0.4 wt pct Mg alloy," Metallurgical and Materials Transactions A, vol. 27, no. 12, pp. 3983-3991, 1996.

[38] H.K. Kang, M. Kida, and H. Miyahara, "Age hardening characteristics of Al-Si-Cu-Base cast alloys," AFS Transactions, vol. 107, pp. 507-515, 1999.

[39] S. Zafar, N. Ikram, M. A. Shaikh, and K. A. Shoaib, "Microstructure studies in $\mathrm{Al}-6 \% \mathrm{Si}-1.9 \% \mathrm{Cu}-\mathrm{X} \% \mathrm{Mg}$ alloys," Journal of Materials Science, vol. 25, no. 5, pp. 2595-2597, 1990.

[40] M. H. Mulazimoglu, R. A. L. Drew, and J. E. Gruzleski, “The electrical conductivity of cast Al-Si alloys in the range of 2 12.6 wt.\% silicon," Metallurgical Transactions A, vol. 20, no. 3, pp. 383-389, 1996. 


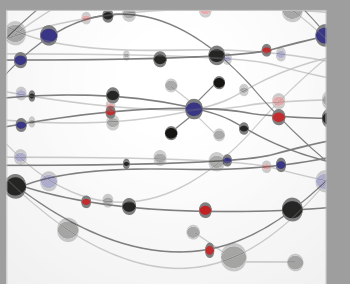

The Scientific World Journal
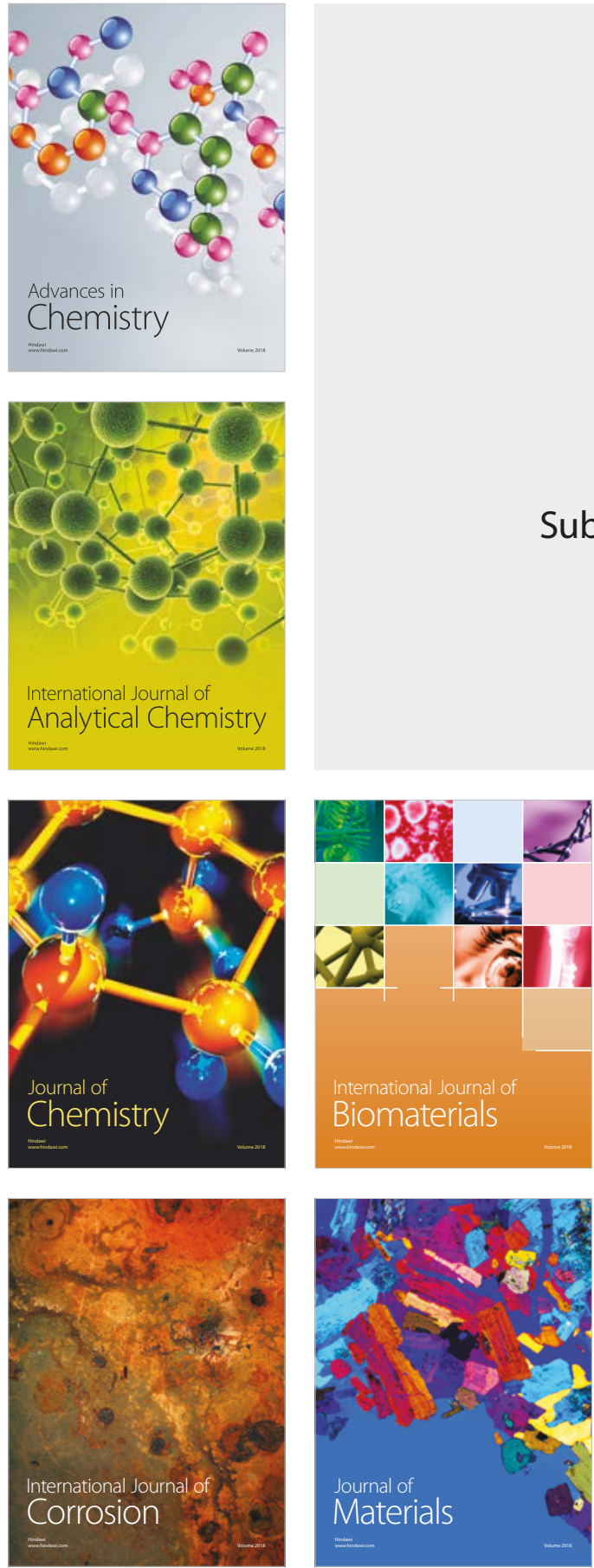

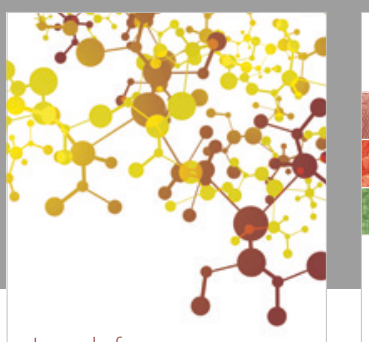

Journal of

Applied Chemistry
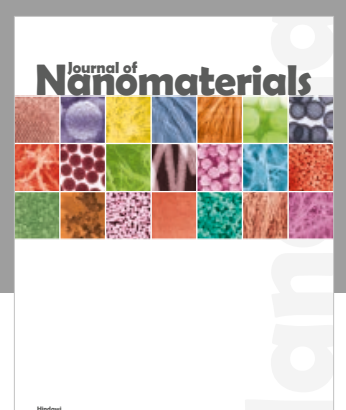

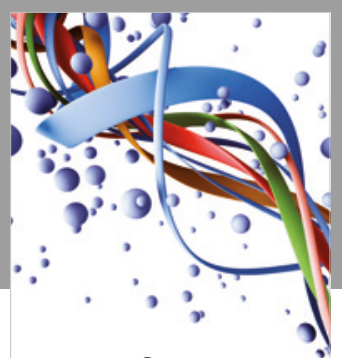

Scientifica

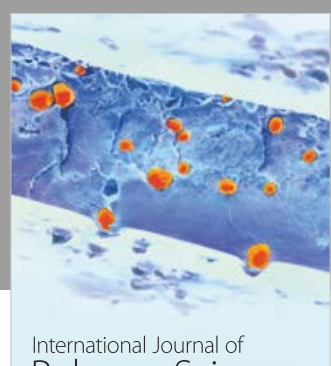

Polymer Science

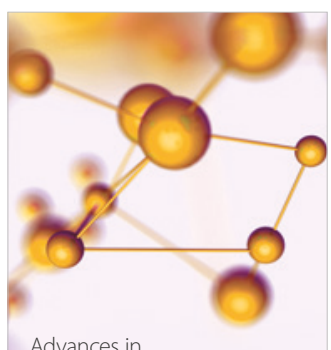

Physical Chemistry
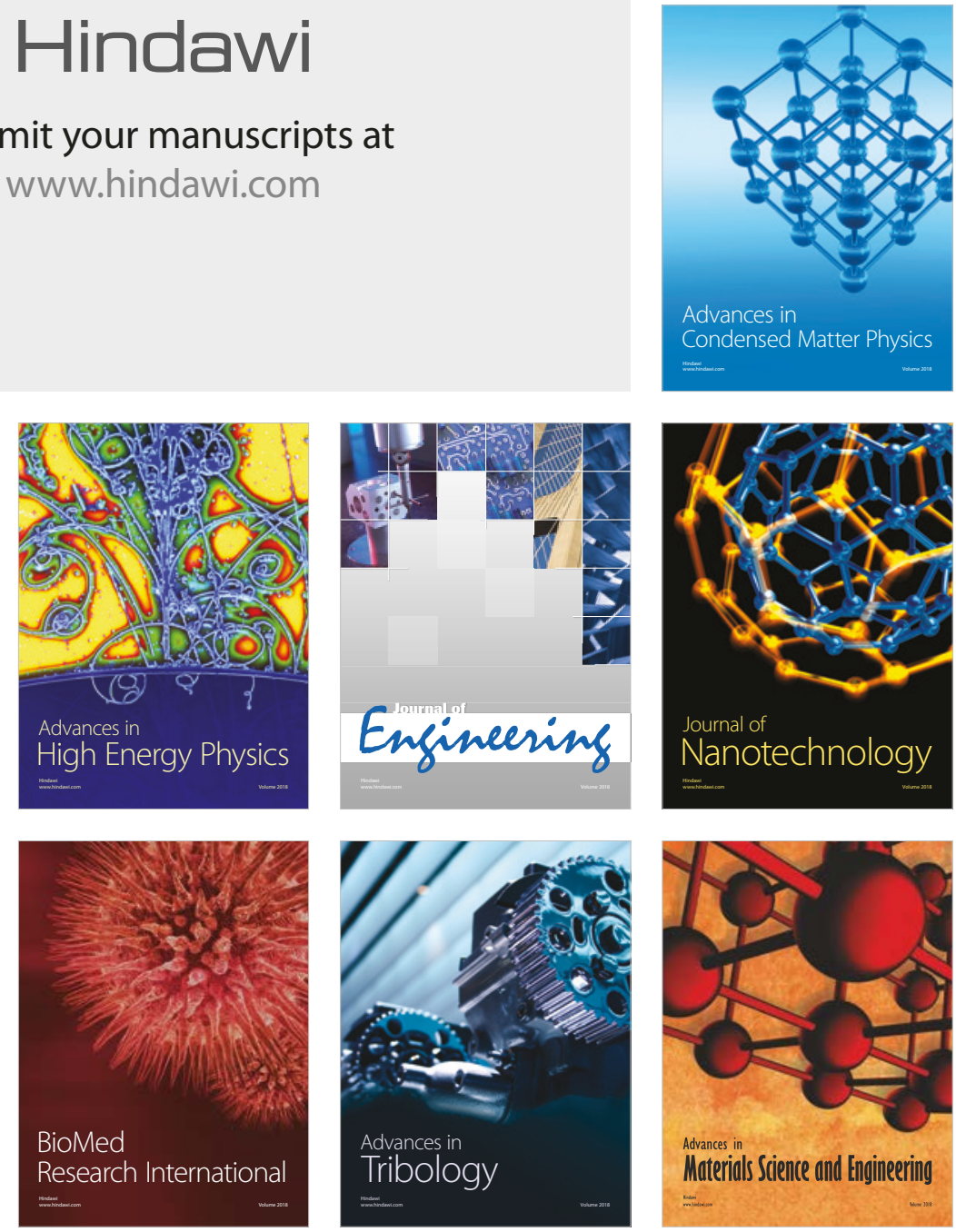